Tropical Journal of Pharmaceutical Research November 2017; 16 (11): 2705-2711

ISSN: $1596-5996$ (print); 1596-9827 (electronic)

(c) Pharmacotherapy Group, Faculty of Pharmacy, University of Benin, Benin City, 300001 Nigeria.

All rights reserved.

Available online at http://www.tjpr.org

Original Research Article

http://dx.doi.org/10.4314/tjpr.v16i11.19

\title{
In vitro assessment of activity of graphene silver composite sheets against multidrug-resistant bacteria and Tomato Bushy Stunt Virus
}

\author{
Ahmed M Elazzazy ${ }^{1,2 \star}$, Essam KF Elbeshehy ${ }^{1,3}$ and Mohamed A Betiha ${ }^{4}$ \\ ${ }^{1}$ Biological Sciences Department, Faculty of Science, University of Jeddah, Jeddah, Saudi Arabia, ${ }^{2}$ Chemistry of Natural and \\ Microbial Products Department, National Research Center, Dokki, Giza, ${ }^{3}$ Department of Agricultural Botany, Faculty of \\ Agriculture, Suez Canal University, ${ }^{4}$ Egyptian Petroleum Research Institute, Nasr City, Cairo 11727, Egypt
}

*For correspondence: Email: Ahmedazazy8@hotmail.com; Tel: 0096-6560922828

Revised accepted: 24 October 2017

\begin{abstract}
Purpose: To synthesize graphene-based silver nanocomposites and evaluate their antimicrobial and anti-Tomato Bushy Stunt Virus (TBSV) activities.

Methods: A graphene-based silver composite was prepared by adsorbing silver nanoparticles AgNPs to the surfaces of graphene oxide (GO) sheets. Scanning electron microscopy was used to analyze the morphology of the synthesized graphene-based silver nanocomposite. This compound was investigated for its antimicrobial activity against several multidrug-resistant human pathogens using the agar well diffusion technique. Moreover, the biocompatibility and antiviral activity of the graphene-based nanocomposite against TBSV was studied in lettuce.

Results: The graphene-based silver composite exhibited remarkable antimicrobial effects against pathogenic bacteria including Shigella sonnei and Pseudomonas aeruginosa with zones of inhibition of $32 \pm 0.11$ and $29 \pm 0.05 \mathrm{~mm}$, respectively. They inhibited TBSV better than graphene and GO.

Conclusion: The synthesized graphene-based silver composite exhibits potent activity against TBSV and multidrug resistant bacteria, indicating that they are good candidates for future therapeutic applications.
\end{abstract}

Keywords: Graphene oxide, Graphene-based nanocomposite, Antiviral, Antimicrobial, Multidrugresistant (MDR) human pathogens

Tropical Journal of Pharmaceutical Research is indexed by Science Citation Index (SciSearch), Scopus, International Pharmaceutical Abstract, Chemical Abstracts, Embase, Index Copernicus, EBSCO, African Index Medicus, JournalSeek, Journal Citation Reports/Science Edition, Directory of Open Access Journals (DOAJ), African Journal Online, Bioline International, Open-J-Gate and Pharmacy Abstracts

\section{INTRODUCTION}

The most versatile application for graphene is its use in composite materials. Low production costs make graphene-based composites attractive and competitive for a variety of uses [1-3]. The most important characteristics of graphene oxide (GO) are low cytotoxicity, good colloidal behavior, large surface area and low cost [3]. GO is applied in medicine, agriculture, food, aerospace, electronics and defense industries [4]. The literature reports positive effects of carbon nanotubes on plant growth and development, such as increased of root growth of onion cucumber and rye-grass in response to carbon nanotubes [5]. The nanotubes likely stimulate cell division and plant growth by activating aquaporins and major gene regulators of cell division and extension [6].

Tomato bushy stunt virus (TBSV) is distributed all over the world, including Central and Western Europe, North Africa and the USA [7]. Dieback and necrosis of romaine and leaf lettuce caused 
by TBSV TBSV- have become increasingly important in California and the incidence is becoming more widespread [8,9]. Recently, nanoscale materials have been raised as novel microbial killers because of their unique chemical and physical properties and their large surface area to volume ratio. The antimicrobial characteristics of graphene-based composite materials have promoted their use in medical and ecological applications and various consumer goods [10].

The present work investigated the development and analysis of graphene-based antimicrobial and antiviral agents.

\section{EXPERIMENTAL}

\section{Preparation of graphene oxide}

Graphite (5 g), $2.5 \mathrm{~g} \mathrm{NaNO}_{3}$ and $110 \mathrm{~mL} \mathrm{H}_{2} \mathrm{SO}_{4}$ were mixed at $0{ }^{\circ} \mathrm{C}$. Thereafter, $15 \mathrm{~g}$ of $\mathrm{KMnO}_{4}$ were added. The suspension was diluted with $500 \mathrm{ml}$ of $25^{\circ} \mathrm{C}$ water and treated with $100-200$ $\mathrm{mL} 30 \% \mathrm{H}_{2} \mathrm{O}_{2}$ to reduce the residual $\mathrm{KMnO}_{4}$. When the suspension turned bright yellow, it was filtered and washed. The resulting yellowishbrown cake was vacuum dried overnight at room temperature $[11,12]$.

\section{In-situ preparation of nanosilver on graphene oxide}

GO (1.0 g) was dispersed in $75 \mathrm{ml}$ double distilled water. To this solution, the required amount of silver nitrate and tri-sodium citrate were added $\left\{\left(\mathrm{AgNO}_{3}\right)\right.$ : (trisodium citrate) $\left.=2\right\}$. The solution was heated at $130{ }^{\circ} \mathrm{C}$ with vigorous stirring for $60 \mathrm{~min}$. The highly-viscous solution was cooled to $-5{ }^{\circ} \mathrm{C}$. The excess water was removed under vacuum and the product stored in a dry place.

\section{Test microorganisms}

The antimicrobial activity of graphene, GO and the graphene-based silver nanoparticles (GOAgNPs) were tested in vitro against human pathogens including Shigella sonnei ATCC 25931, Escherichia coli ATCC 25922, Pseudomonas aeruginosa ATCC BAA-2108, Klebsiella oxytoca ATCC 51983, Streptococcus bovis ATCC 49147, methicillin-resistant Staphylococcus aureus ATCC 43330 and Candida albicans ATCC 10221.

The isolates were obtained from King Abdulaziz University Medical Center, Jeddah, Saudi Arabia, on nutrient agar plates.

\section{Agar-well diffusion method}

The antimicrobial potential of graphene, GO and GO-AgNPs against the selected isolates was evaluated using agar-well diffusion assay. Fresh overnight cultures of the bacteria $(100 \mu \mathrm{L})$ were inoculated into Muller-Hinton broth and incubated at $30{ }^{\circ} \mathrm{C}$ in a shaking incubator. After incubation, the optical density was adjusted to 0.5 McFarland standards, then $1 \mathrm{~mL}$ $\left(10^{6} \mathrm{CFU} / \mathrm{mL}\right)$ was swabbed onto Mueller Hinton Il-agar plates and allowed to dry for $5 \mathrm{~min}$. Afterwards, graphene and graphene-based molecules were placed in a well in the agar using a sterile micropipette. Plates were incubated overnight at $37^{\circ} \mathrm{C}$ and the inhibition zone diameter (IZD) were measured using Clinical \& Laboratory Standards Institute guidelines.

\section{TBSV}

TBSV was collected from random Capsicum annuum (pepper) samples from different fields in Egypt in 2016. Samples were tested for TBSV by the tissue blotting technique (TBPA) as described by [13,14], using polyclonal antibodies specific for TBSV (Agdia, Elkhart, IN, USA). Trans-Blot nitrocellulose membranes (BioRad Laboratories, CA) were used in this study.

\section{Propagation of Egyptian isolate of TBSV}

Infected sap was prepared from upper infected leaves and used for inoculation in $0.01 \mathrm{M}$ sodium phosphate buffer (pH 7.0). The virus was biologically purified using the single local lesions system and further propagated in lettuce (Lactuca sativa) by mechanical inoculation.

\section{Greenhouse experiments}

Susceptible cultivars from lettuce seeds were germinated and grown in pots. After 25 days of planting, Lettuce seedlings were inoculated with TBSV. Four solutions were prepared containing buffer (control), graphene ( $\mathrm{Gr} 1 \mathrm{mg} / \mathrm{mL})$, GOAgNPs (1 mg/mL) and $\mathrm{GO}(12,6,3$ and 1.5 $\mu \mathrm{g} / \mathrm{mL})$, respectively

Lettuce plants were inoculated in a randomized block design with three seedlings per pot, one pot per replicate, and four replicates per treatment (total 12 seedlings per treatment). The TBPA test and observation of symptoms were used for checking the presence of the virus.

The graphene (Gr), GO and GO-AgNP treatments were: Treatment 1: control healthy; 
Treatment 2: control infected; Treatment 3: $\mathrm{Gr} 1$ $\mathrm{mg} / \mathrm{mL}$ with TBSV; Treatment 4: GO-AgNPs 1 $\mathrm{mg} / \mathrm{ml}$ with TBSV; Treatment 5: GO $12 \mu \mathrm{g} / \mathrm{ml}$ with TBSV; Treatment 6: GO $6 \mu \mathrm{g} / \mathrm{mL}$ with TBSV; Treatment 7: GO $3 \mu \mathrm{g} / \mathrm{mL}$ with TBSV; and Treatment 8: GO $1.5 \mu \mathrm{g} / \mathrm{mL}$ with TBSV. After 3 weeks of TBSV inoculation, plants were selected and examined for the presence and effects of TBSV. Level of infection and disease severity were recorded according to the scale: $0=$ no symptoms; 1 = light dieback; 2 = dieback and stunting; $3=$ chlorotic ring spot and dwarfism; $4=$ dieback, necrosis and bushy stunting. Values of disease severity (DS) were calculated using Eq. 1 [15].

$\mathrm{DS}(\%)=\{(\mathrm{DV}) /(\mathrm{NH})\} 100$

where: $\mathrm{D}=$ disease grade; $\mathrm{V}=$ number of plants of each class; $\mathrm{N}=$ total of observed plants; $\mathrm{H}=$ highest value on the evaluation scale.

\section{Statistical analysis}

Data were analyzed using SPSS v. 22 software, and the results are presented as mean $\pm S D(n=$ 3). Comparison of means between different groups was performed using one-way analysis of variance. Statistical significance was defined as $p<0.05$.

\section{RESULTS}

\section{Characteristics of Gr, GO and GO-AgNPs}

Fig. $1 \mathrm{~A}$ shows the regular graphene oxide sheet. Fig. 1B shows scanning electron microscope images of the synthesized hybrid; AgNPs were deposited uniformly on the GO surface with size distribution $30-50 \mathrm{~nm}$. The resultant hybrids formed well-dispersed aqueous colloids.

\section{Antimicrobial activity}

Table 1 shows the results of antimicrobial assay of Gr, GO and the GO-AgNP composite. After incubation at $37{ }^{\circ} \mathrm{C}$ for $24 \mathrm{~h}$ with $\mathrm{Gr}$ or $\mathrm{GO}$, no inhibition zone was observed for the fungus C. albicans. For GO-AgNP, an inhibition zone was obvious after incubation for $8 \mathrm{~h}$. The GOAgNPs were effective antimicrobials against all the bacteria tested, with similar activity against each tested strain. The antimicrobial activity of $\mathrm{GO}$ was much less than that of GO-AgNPs for all the strains. GO showed greater antibacterial activity than graphene.
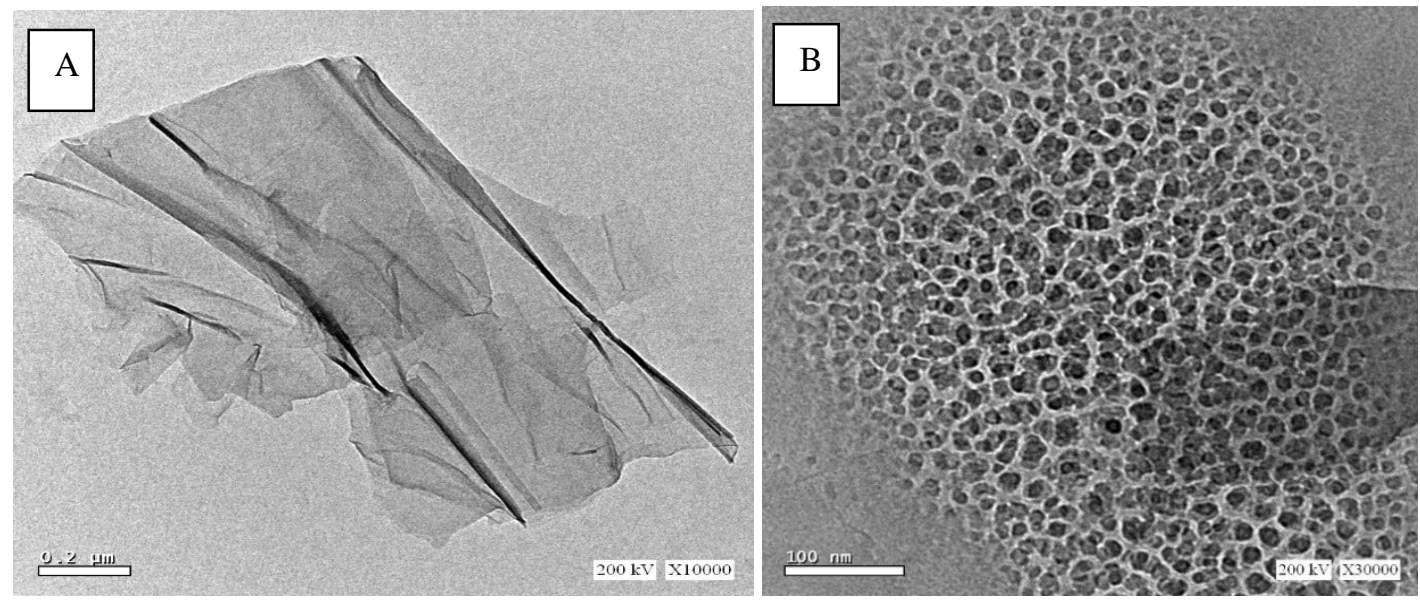

Figure 1: Scanning electron microscope images of graphene oxide (A) and graphene-based nanosilver (B)

Table 1: Antimicrobial activity of graphene (Gr), graphene oxide (GO) and graphene-based nanosilver (GOAgNPs) toward pathogenic strains

\begin{tabular}{lccc} 
Pathogenic strain & \multicolumn{3}{c}{ Inhibition zone (mm) } \\
\cline { 2 - 4 } & Gr & GO & GO-AgNPs \\
\hline Escherichia coli ATCC 25922 & $10 \pm 0.2$ & $14 \pm 0.1$ & $25 \pm 0.03$ \\
Pseudomonas aeruginosa ATCC BAA-2108 & $11 \pm 0.17$ & $14 \pm 0.45$ & $29 \pm 0.05$ \\
Staphylococcus aureus (MRSA) ATCC 43330 & $11 \pm 0.28$ & $17 \pm 0.15$ & $28 \pm 0.08$ \\
Klebsiella oxytoca ATCC 51983 & $10 \pm 0.19$ & $13 \pm 0.02$ & $28 \pm 0.057$ \\
Candida albicans ATCC 10221 & $0 \pm 0.00$ & $0 \pm 0.00$ & $22 \pm 0.10$ \\
Shigella sonnei ATCC 25931 & $9 \pm 0.01$ & $18 \pm 0.03$ & $32 \pm 0.11$ \\
Streptococcus bovis ATCC 49147 & $11 \pm 0.05$ & $18 \pm 0.04$ & $26 \pm 0.12$ \\
\hline
\end{tabular}




\section{Source of virus inoculum}

Naturally infected pepper leaves showing symptoms of TBSV infection (dieback, necrosis and bushy stunting) were collected from fields in Egypt (Figure 2) and gave a positive reaction in the TBPA test for the presence of TBSV using TBSV-specific polyclonal antibodies.

\section{Propagation of Egyptian isolate of TBSV}

Pepper leaves with typical viral symptoms were used to prepare sap for inoculation. The virus was transferred into the local lesion host Gomphrena globosa. Single local lesions were isolated and propagated further in lettuce $(L$. sativa) by mechanical inoculation. Infected lettuce plants which give positive reactions in the TBPA test became sources of TBSV for testing the activity of $\mathrm{Gr}$ and derivatives against TBSV.

\section{Antiviral activity of $\mathrm{Gr}, \mathrm{GO}$ and its AgNP composite}

In vivo screening of the antiviral activities of $\mathrm{Gr}$, GO and its AgNP composite against TBSV was performed using a local lettuce cultivar. Typical symptoms of TBSV were observed in inoculated lettuce seedlings compared with non-inoculated plants. Severe viral infection was observed for the control infected treatment. Spread treatment with graphene and the GO-AgNP composite reduced the TBSV symptoms in inoculated lettuce seedlings. These treatments also decreased the virus concentration, infection percentage and disease severity of inoculated lettuce seedlings in comparison with infected controls. Table 2 and Figure 3 show that postinoculation treatment with GO-AgNPs resulted in a higher activity against TBSV than was observed for GO. The data in Table 2 indicate that the effect on disease severity did vary depending on the $\mathrm{GO}$ concentration.

\section{DISCUSSION}

AgNPs were uniformly deposited on the GO surface with; the resultant hybrids formed welldispersed aqueous colloids. Similar findings were reported previously $[16,17]$.

In antimicrobial tests, GO-AgNPs inhibited all the test bacteria, to approximately the same extent for each strain. The antimicrobial activity of GO was much less than that of the GO-AgNPs toward the same pathogens in the same conditions.

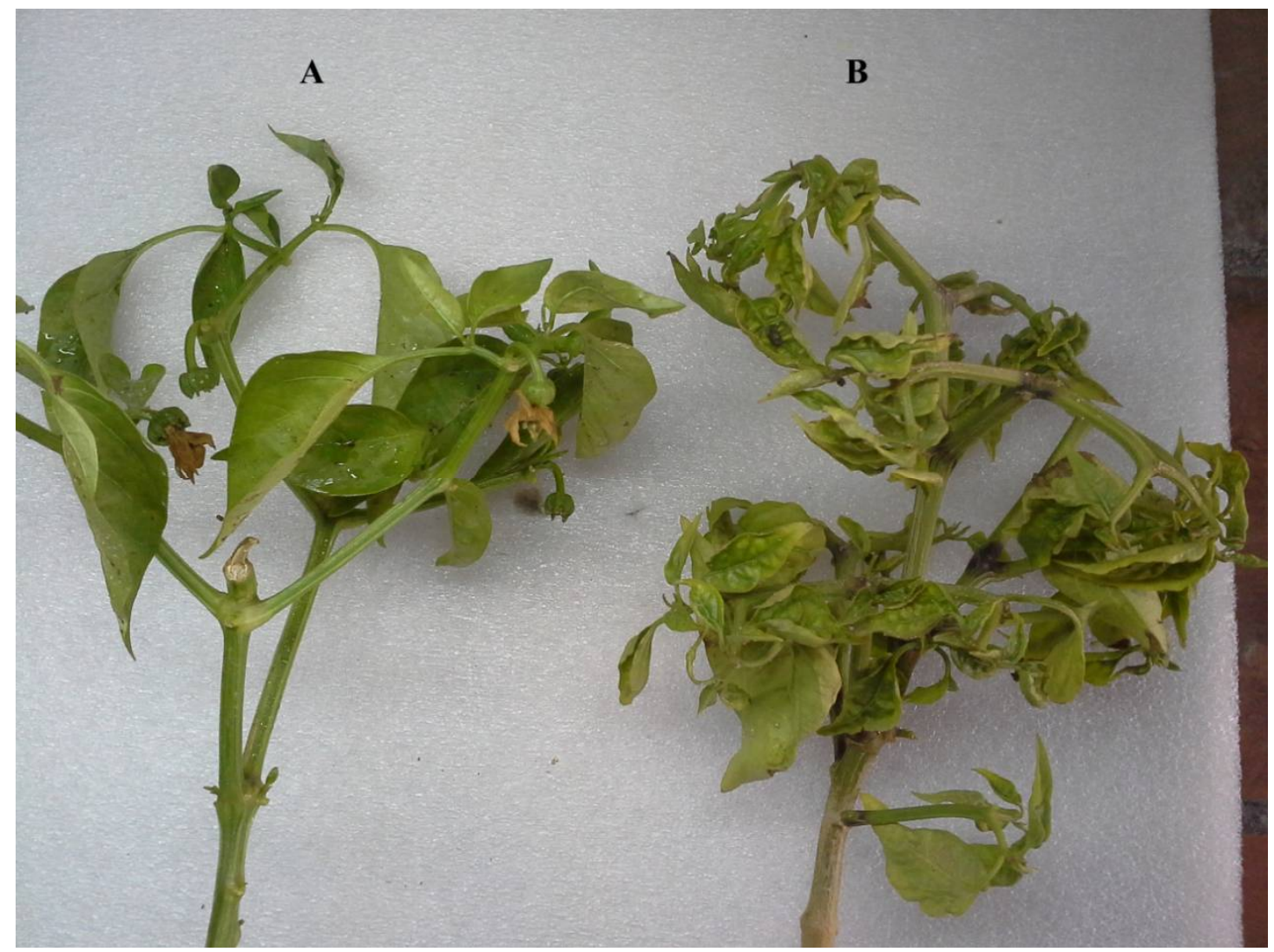

Figure 2: Tomato bushy stunt virus (TBSV) isolation and identification: symptoms caused by natural TBSV infection of pepper leaves collected in Egypt. (A) Healthy plant and (B) infected plant showing dieback, necrosis and bushy stunting 
Table 2: Effect of different concentrations of graphene, graphene oxide and graphene-based nanosilver on virus appearance, Virus infectivity (I) and disease severity (DS) of a susceptible lettuce cultivar.

\begin{tabular}{|c|c|c|c|c|c|c|c|c|c|c|c|c|c|c|c|c|c|c|c|}
\hline \multirow[t]{3}{*}{$\mathrm{T}$} & \multicolumn{12}{|c|}{ Virus appearance } & \multirow{2}{*}{\multicolumn{5}{|c|}{ Virus infectivity (I) }} & \multirow{2}{*}{\multicolumn{2}{|c|}{$\begin{array}{c}\text { Disease severity } \\
(\%)\end{array}$}} \\
\hline & \multicolumn{3}{|c|}{ R1 } & \multicolumn{3}{|c|}{ R2 } & \multicolumn{3}{|c|}{ R3 } & \multicolumn{3}{|c|}{ R4 } & & & & & & & \\
\hline & $r_{1}$ & $r_{2}$ & $r_{3}$ & $r_{1}$ & $r_{2}$ & $r_{3}$ & $r_{1}$ & $r_{2}$ & $r_{3}$ & $r_{1}$ & $r_{2}$ & $r_{3}$ & $\mathrm{R} 1$ & $\mathrm{R} 2$ & R3 & R4 & $(\%)$ & $\mathrm{DG}$ & $\mathrm{DS} \%$ \\
\hline T1 & - & - & - & - & - & - & - & - & - & - & - & - & $0 / 3$ & $0 / 3$ & $0 / 3$ & $0 / 3$ & 0 & 0 & 0 \\
\hline $\mathrm{T} 2$ & + & + & + & + & + & + & + & + & + & + & + & + & $3 / 3$ & $3 / 3$ & $3 / 3$ & $3 / 3$ & 100 & 4 & 100 \\
\hline T3 & - & - & - & - & - & - & + & - & - & - & - & + & $0 / 3$ & $0 / 3$ & $1 / 3$ & $1 / 3$ & 16.67 & 1 & 4.17 \\
\hline $\mathrm{T} 4$ & + & - & - & - & - & + & - & - & - & - & + & - & $1 / 3$ & $1 / 3$ & $0 / 3$ & $1 / 3$ & 25 & 1 & 6.25 \\
\hline T5 & - & + & + & - & + & + & + & - & + & + & + & + & $2 / 3$ & $2 / 3$ & $2 / 3$ & $3 / 3$ & 75 & 2 & 37.5 \\
\hline T6 & + & + & + & + & + & + & + & + & + & + & + & + & $3 / 3$ & $3 / 3$ & $3 / 3$ & $3 / 3$ & 100 & 4 & 100 \\
\hline $\mathrm{T7}$ & + & + & + & + & + & + & + & + & + & + & + & + & $3 / 3$ & $3 / 3$ & $3 / 3$ & $3 / 3$ & 100 & 2 & 50 \\
\hline T8 & + & + & + & + & + & + & + & + & + & + & + & + & $3 / 3$ & $3 / 3$ & $3 / 3$ & $3 / 3$ & 100 & 1 & 25 \\
\hline
\end{tabular}

Treatment (T) 1: control healthy plants; T2: control infected plants; T3: Gr with TBSV; T4: GO-AgNPs with TBSV; T5: GO $(12 \mu \mathrm{g} / \mathrm{mL})$ with TBSV; T6: GO $(6 \mu \mathrm{g} / \mathrm{mL})$ with TBSV; T7: GO $(3 \mu \mathrm{g} / \mathrm{mL})$ with TBSV; T8: GO $(1.5 \mu \mathrm{g} / \mathrm{mL})$ with TBSV.
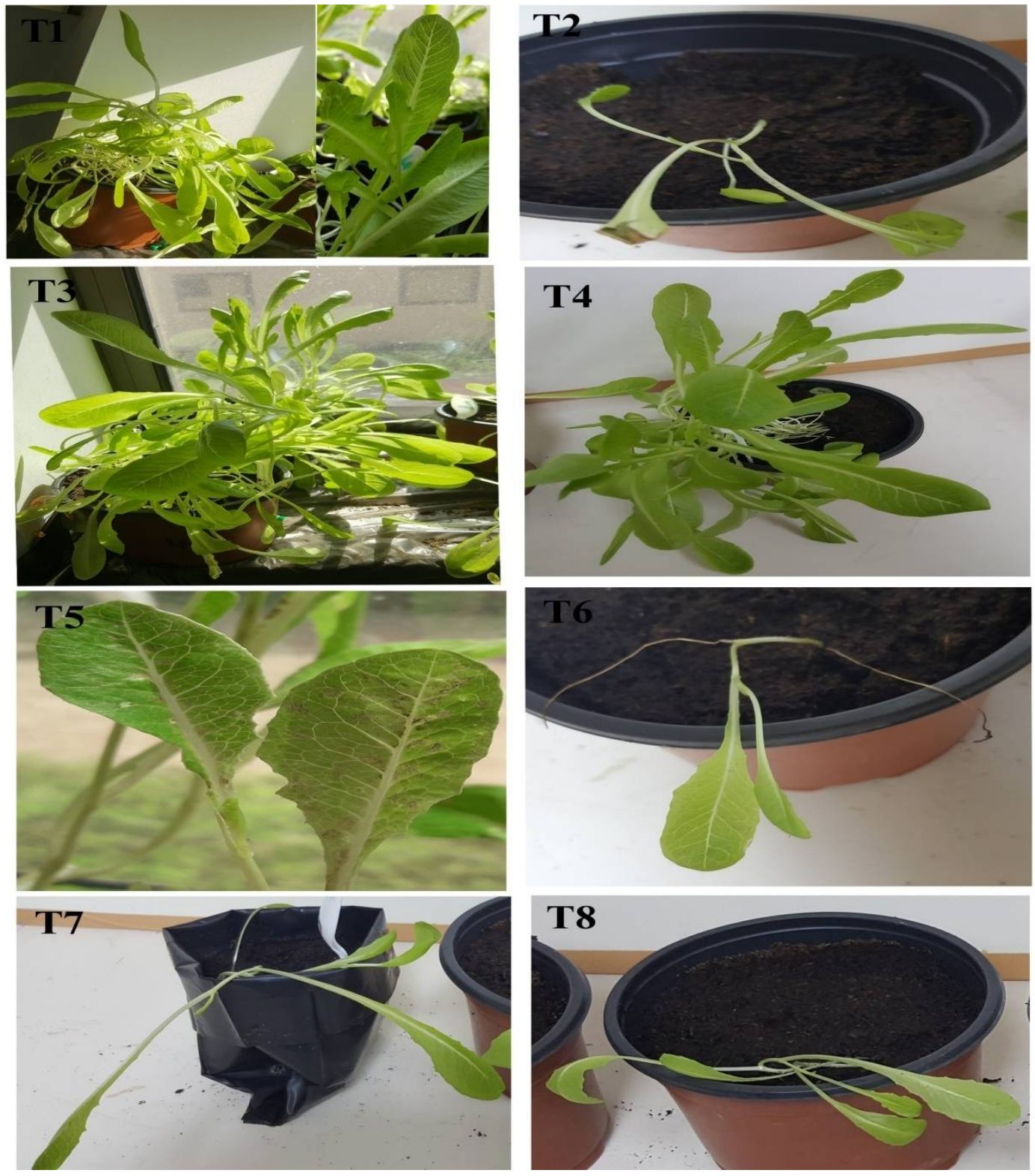

Figure 3: Effect of graphene, graphene-based nanosilver and graphene oxide on a susceptible lettuce cultivar in the presence of TBSV in greenhouse conditions. T1: healthy control; T2 infected control; T3: graphene with TBSV; T4: graphene-based nanosilver with TBSV; T5: graphene oxide (12 $\mu \mathrm{g} / \mathrm{ml})$ with TBSV; T6: graphene oxide $(6 \mu \mathrm{g} / \mathrm{ml})$ with TBSV; T7: graphene oxide $(3 \mu \mathrm{g} / \mathrm{ml})$ with TBSV; T8: graphene oxide $(1.5 \mu \mathrm{g} / \mathrm{ml}$,$) with TBSV$ 
These results correlate with the work reported by Gu et al [18], where addition of silver to graphene increased and prolonged its antimicrobial activity. Bare GO sheets are intrinsically bactericidal (bacterial survival percentage $<1 \%$ at $200 \mu \mathrm{g} / \mathrm{ml}$ ) [19], resulting from the production of superoxide radicals, which caused oxidative stress, DNA fragmentation and loss of cell viability in $P$. aeruginosa [20]. It has also been suggested that the antimicrobial properties of $\mathrm{GO}$ result both from oxidative stress and membrane contact [21]. The enhanced antibacterial activity of GOAgNPs may result from the high stability of AgNPs anchored on the GO sheets, and the positively charged hybrid surface, which increases electrostatic interactions of the bacterial cell membrane with the nanohybrid [22]. Gram-positive bacteria are more sensitive to AgNPs than Gram-negative bacteria because of the interactions of positively charged AgNPs with negatively charged lipopolysaccharides on the bacterial surface [23].

Virus inhibition assays demonstrated that the activity clearly depends on the particle dimension and the spatial distribution of the interacting ligand/receptor molecules between coat proteins of the virus and infected cell receptors. GO and GO-AgNPs may enter the cell and exert antiviral activity through interactions with viral nucleic acids.

The results obtained in this study show that a GO-AgNP composite could be successfully prepared by decorating AgNPs onto the surfaces of GO sheets. The GO-AgNP composite possessed potent and desirable biological activities. The strongly-coupled interaction between Ag nanocrystals and GO, as well as the presence of the $\mathrm{Ag}$ dots, contributed to the antibacterial properties of the GO-AgNP composite.

\section{CONCLUSION}

GO - AgNPs composites have been prepared successfully by layering AgNPs on to the surfaces of GO sheets. The synthesized graphene-based silver composites represent a good lead for the development of potent antiviral agents against TBSV and multidrug resistance bacteria.

\section{DECLARATIONS}

\section{Acknowledgement}

This work was funded by the Deanship of Scientific Research (DSR), University of Jeddah, Jeddah (grant no. G-1436-965-567). The authors, therefore, thank DSR for technical and financial support.

\section{Conflict of Interest}

No conflict of interest associated with this work.

\section{Contribution of Authors}

The authors declare that this work was done by the authors named in this article and all liabilities pertaining to claims relating to the content of this article will be borne by them.

\section{Open Access}

This is an Open Access article that uses a funding model which does not charge readers or their institutions for access and distributed under the terms of the Creative Commons Attribution License (http://creativecommons.org/licenses/by/ 4.0) and the Budapest Open Access Initiative (http://www.budapestopenaccessinitiative.org/rea d), which permit unrestricted use, distribution, and reproduction in any medium, provided the original work is properly credited.

\section{REFERENCES}

1. Sharma BK, Ahn JH. Graphene based field effect transistors: Efforts made towards flexible electronics. Solid-State Electron 2013; 89: 177-188.

2. Amer A, Ahmed S, Reda M, Mousa MA, Mohamed MM. Mn304/graphene nanocomposites: outstanding performances as highly efficient photocatalysts and microwave absorbers. RSC Adv 2017; 7: 826-839.

3. Burgos JC, Reyna H, Yakobson B, Balbuena P. Interplay of Catalyst Size and Metal-Carbon Interactions in the Growth of Single Wall Carbon Nanotubes. J Phys Chem C 2010; 114: 6952-6958.

4. Nikalje AP. Nanotechnology and its Applications in Medicine. Med Chem 2015; 5: 081-089.

5. Khodakovskaya MV, Kim BS, Kim JN, Alimohammadi M, Dervishi E, Mustafa T, Cernigla CE. Carbon nanotubes as plant growth regulators: effects on tomato growth, reproductive system and soil microbial community. Small 2013; 9(1): 115-123.

6. Lahiani MH, Dervishi E, Chen J, Nima Z, Gaume A, Biris AS, Khodakovskaya MV. Impact of carbon nanotube exposure to seeds of valuable crops. ACS Appl Mater Interfaces 2013; 5: 7965-7973.

7. Russo M, Burgyan J, Martelli GP. Molecular biology of Tombusviridae. Adv Virus Res 1994; 44: 381-428.

8. Martelli GP, Russo M, Rubbino M. Tomato bushy stunt virus, A.A.B. Descriptions of Plant Viruses 2001; 382.

9. Liu HY, Sears JL, Obermeier C, Wisler GC, Ryder EJ, Duffus, JE, Koike ST. First report of tomato bushy stunt 
virus isolated from lettuce. Plant Dis 1999; 83: 301.

10. Yakobson B, Ding F. Observational geology of graphene, at the nanoscale. ACS Nano 2011; 5: 1569-1574.

11. Hassan MH, Victor A, Abd El Rahman SKh, Khaled MA, James T, Samy M, Saud I, Al-Resayesb Adel A. Microwave synthesis of graphene sheets supporting metal nanocrystals in aqueous and organic media. $J$ Mater Chem 2009; 19: 3832-3837.

12. Yadav, RK, Jin-Ook B, Gyu HO, No-Joong P, Ki-jeong K, Jinheung $K$, Dong $W H$, Soumya KB. A photocatalystenzyme coupled artificial photosynthesis system for solar energy in production of formic acid from CO2. J Am Chem Soc 2012; 134: 11455-11461.

13. Lin $H X, X u W$, White KA. A multicomponent RNA-based control system regulates subgenomic mRNA transcription in a tombusvirus. J Virol 2007; 81: 2429 2439.

14. Garnsey SM, Permar TA, Cambra M, Henderson CT. Direct tissue blot immunoassay (DTBIA) for detection of citrus tristeza virus (CTV). Proc 12th Conf of IOCV, India, 1998; pp 39-50.

15. Yang $X$, Liangyi $K$, Tien $P$. Resistance of tomato infected with Cucumber mosaic virus satellite RNA to potato spindle tuber viroid. Ann Appl. Biol 1996; 129: 543-51.

16. Zhou Y, Bao QL, Tang LAL, Zhong YL, Loh KP. Hydrothermal dehydration for the "green" reduction of exfoliated graphene oxide to graphene and demonstration of tunable optical limiting properties. Chem Mater 2009; 21: 2950-2956.
17. Liu M, Zhao HM, Chen S, Yu HT, Quan X. Interface engineering catalytic graphene for smart colorimetric biosensing. ACS Nano 2012; 6: 3142-3151.

18. Gu D, Xueting $C$, Xinxin Z, Shibin S. Efficient synthesis of silver-reduced graphene oxide composites with prolonged antibacterial effects. Ceramics International 2016; 42: 9769-9778.

19. Hui L, Piao JG, Auletta J, Hu K, Zhu Y, Meyer T, Liu H, Yang L. Availability of the Basal Planes of Graphene Oxide Determines Whether It Is Antibacterial. ACS Appl Mater Interfaces 2014; 6: 13183-13190.

20. Gurunathan S, Han JW, Dayem AA, Eppakayala V, Kim $\mathrm{JH}$. Oxidative Stress-Mediated Antibacterial Activity of Graphene Oxide and Reduced Graphene Oxide in Pseudomonas aeruginosa. Int J Nanomedicine 2012; 7: 5901-5914.

21. Singh $Z$, Singh $R$. Toxicity of Graphene Based Nanomaterials towards Different Bacterial Strains: $A$ Comprehensive Review. American Journal of Life Sciences. Special Issue: Environ Toxicol 2017; 5: 1-9.

22. Zhu Z, Su M, Ma L, Ma L, Liu D, Wang Z. Preparation of Graphene Oxide-Silver Nanoparticle Nanohybrids With Highly Antibacterial Capability. Talanta 2013; 117: 449455.

23. Mahmoud WM, Abdelmoneim TS, Elazzazy AM. The impact of silver nanoparticles produced by Bacillus pumilus as antimicrobial and nematicide. Front Microbiol 2016; 7:174610.3389/fmicb.2016.01746. 